\title{
3 Swedish total defence and the emergence of societal security
}

\author{
Sebastian Larsson
}

\section{Introduction}

Over the past few decades, the notion of "societal security" has emerged as a way to conceptualise Nordic and European security beyond the traditional framework of territorial security and military defence. The terminology has been utilised by Swedish and Norwegian governments and security agencies, for example, to describe their "all-hazards" approach towards crisis management and counterterrorism (DSB 2019; FOI 2013; MSB 2011); it has been introduced in the context of Nordic inter-ministerial and Nordic Council cooperation as a way to propose a Nordic "model" for security (Sandö and Bailes 2014; Stoltenberg 2009; see also Introduction, this volume); it has been used as the overarching theme for security-related research and development (R\&D) at the EU level (Bigo and Martin-Mazé 2014; European Commission 2018); and recently, it has even been subject to commercial and organisational standardisation by the International Organization for Standardization (ISO/TC 223 2016; ISO/TC 292 2016).

Closely associated with the post-Cold War generation of security practitioners and scholars, societal security makes the bold assumption that society is under attack, and that security has to be done either in its name, or somehow by society itself (Larsson 2019; SOURCE 2016). Through the logic of societal security, it is not the sovereign state but a fabric of functions and values underpinning a certain way of life that is assumed to be the target. The antagonist is assumed to be not an invading army, but some internal or "asymmetrical" threat such as a terrorist or a criminal. The threat is, more generally, reconfigured from known and certain to increasingly uncertain and insidious, and related to transgressive human-induced or environmental disasters. The practice of security must therefore also be reframed and conceived of holistically, involving a range of new actors, strategies, and technologies, and offered for - or even by - society itself. In brief, it is safe to say that the notion of societal security both in practice and theory - matters for how security is conceived of and acted upon. However, we know less about its origin and evolution over time.

Departing from the two first chapters of this volume, this contribution asks not what societal security "is" or "means", but more specifically where it comes from by studying the underlying social and historical conditions for 
its emergence. Indeed, most questions regarding what can be called the "sociogenesis" of societal security have been left unanswered thus far. Among which organisations and individuals did it emerge? From which ideational heritage has it developed? To what extent does it signify a "new" way of doing and thinking security? As discussed in the introduction of this volume, as well as in a report from 2014 (Bigo and Martin-Mazé 2014, 8-14), the functionalist ${ }^{1}$ understanding and concept of societal security was formulated by actors from the Nordic region, and in Sweden quite prominently. By analysing the transformations of the Swedish defence sector after the Cold War, this chapter locates the origins of societal security in this particular environment, illustrating how its emergence was in fact not the result of some wider democratic push for demilitarisation, nor some intellectual debate on how to radically redefine societal issues and security work. Rather, it was connected to a group of high-level bureaucrats and politicians who were working to reform Sweden's model of so-called "total defence" after the end of the Cold War, and in particular, how to modernise its "civil defence" branch. From as early as 1986, certain agency officials, public investigators, policy advisors, and scholars began assembling new security knowledge and imposing threats and risks beyond war-thinking - including strategies for managing "asymmetrical" forms of antagonism and introducing this as the new "security problem" in official discourse - while at the same time seeking to create a shift in practice by establishing new institutions, agency structures, and research environments in the areas of crisis management and counterterrorism. The notion of societal security, it will be argued, emerged not necessarily on its own merit, but as a by-product of this far wider struggle to produce a new "enemy" in Sweden and address the conceptual gap created by the end of the Cold War. Consequently, the notion of societal security is not radically new, but bears significant ideational and practical resemblance to the idea of total defence.

Tracing the sociogenesis of societal security in the renegotiation of Swedish total defence, this chapter draws mainly on archival sources and a series of research interviews, ${ }^{2}$ and proceeds in two sections. The following section discusses how total defence was conceived during Cold War Sweden, how the entire welfare system and civil population was mobilised in war preparedness, and how society - much like in current times - was perceived as at once the asset to be protected and the resource from which to draw. The final section traces, at length and in two chronological steps, key developments in the bureaucratic-political transformation of total defence after the Cold War, beginning with the construction of new threat discourses and security knowledge in the 1990s, followed by the substantial reformations of research and agency ${ }^{3}$ structures in the 2000s.

\section{Society and defence in Cold War Sweden}

Today's common claim that the distinction between the external and internal dimensions of security has become blurred was in fact acknowledged already in the 1940s in Sweden. When a commission was appointed to draft a 
new civil defence law in 1943, it concluded in its final report a year later that the "boundaries between the military and the civil, as well as between theatres of war and the previously preserved homeland, have to a large extent been erased. War has become total" (SOU 1944, 47). "Total warfare against the homeland, where civil life is the primary target", it further declared, "needs to be countered with total defence, including both a military and civil side" (48). Here, in the midst of the Second World War, the idea of "total defence" began to emerge in the Swedish defence sector. Gradually substantialised over the following Cold War decades, this model came to signify not a specific agency nor a fixed institutional structure, but an ideal model for the security of society wherein military defence became intertwined with the civil population, everyday life, and virtually all functions of the public welfare apparatus (Artéus and Fältström 2011, 9, 19-20).

More specifically, total defence came to be categorised and administered as four different branches, (a) military defence, including the army, navy, air force, and reserves, as well as a comprehensive domestic arms industry; (b) economic defence, including storage and supply of fuel, medicine, food, armaments, and other key provisions; (c) psychological defence, including public broadcasting media and counter-disinformation campaigns; and (d) civil defence, including air raid shelters and bunkers, rescue services, evacuation planning, and more (Ministry of Defence Sweden 1995a; Von Konow 1961, 15). The "totality" of these elements was always stressed; in other words, the various forms of defence only worked if assembled together.

The branch with the largest role in peacetime society was arguably that of civil defence. During the Cold War, the government sought to promote a "collective mindset" and "culture" of voluntary civilian participation in extensive war preparedness. This narrative was backed up with the law of "civil defence duty" (tjänsteplikt), obliging every civilian between 16 and 70 years of age, every registered household, and even private property such as buses or trucks to fulfil a specific function in the fortification of Sweden. In addition to civil defence, the military was based on the conscription of all abled-bodied males between 18 and 47 years of age, mobilising up to 850,000 individuals (Total Defence Information Committee 1980, 12; see also Kronsell and Svedberg 2006). Taken together, the defence organisation was to be conceived of as an "enterprise with 4.5 million shareholders in national security". 4 Anthropologists have likened the widespread sociopsychological and infrastructural effect of total defence - and particularly civil defence and the mass-construction of civil and military fortifications during the Cold War - to that of the christening of Sweden and the spreading of churches around the 12th century (Palmblad 2005, 10-11).

The central justification behind these policies was the government's intention of wartime "neutrality" and peacetime "non-alignment". Instead of joining alliances like NATO after the wars, the government and parliament chose the political line of "make do by yourself" and the strategy of self-preservation in terms of national security. Maintaining a "credible" neutrality not only necessitated mass-conscription and a deeply embedded 
civil defence, it was assumed, but also a near-autonomous domestic arms industry which, instead of importing certain weapon systems, could facilitate R\&D in all categories of military supply.

As noted already in the 1960s, the total defence effort came to systematically securitise everything from Sweden's "governance and administration structure [to] its businesses, factories, and industries, its mines, shipyards, and production facilities, its communications, its cities and countryside in short, everything that constitutes the societal organism" (Von Konow 1961, 23). Just like an "environmental"- or "sustainability"-dimension tends to be present in most societal planning today, Cold War Sweden was as a whole designed around a "war dimension", and different invasion scenarios were present in the early stages of virtually all forms of peacetime planning. Indeed, at the time, "[p]lanning became the fashion of the day and the modus operandi of the state" when it came to national security (Lundin and Stenlås 2010,15$)$. This was eventually formulated in terms of the "BIS-model", or the "preparedness model for societal planning". 5 The BIS-model strived for "robustness" (akin to today's idea of resilience) across infrastructural sectors: in logistics, construction, commerce, healthcare, transport, roads, telecommunications, energy and water supply, public and private housing, urban landscaping, and so on. With this pan-sectoral logic, public administration and coordination for defence purposes had to be largely centralised, something which was made possible at the time since most infrastructures, as different from today, were owned and operated as state agencies. ${ }^{6}$

However, total defence proponents realised that for extensive war preparedness to work, it must not only involve actors in and around the state but also had to include the private sector. This can be illustrated by the role of the Institute for Higher Total Defence Education (IHT). A training institution founded in 1952 and responsible for educating the societal elite in the organisation and operation of total defence, IHT was supposedly "more or less unique in the world" in how it managed to gather agency directors, senior state officials, and military staff from across the country as well as highlevel civilians from the corporate world for several weeks of wargaming and networking - like a "playhouse" for defence professionals in the early stages of the Cold War. A central goal behind this rather Millsian structure of interlinked civil-military, public-private elites (Mills 1956) was to bind together an influential "network across private businesses, ${ }^{7}$ public agencies, and the military organisation" that would be able to ensure "impact and acceptance in the political field" from the 1950s and onwards. ${ }^{8}$

Despite its centralised, top-down structuration, total defence was at the same time designed for embedding defence practices "organically" into everyday life, so that they would become part and parcel of the welfare system, of society, or what Foucault $(2007,30)$ calls the "milieu of life, existence, and work" itself (see also Lundin, Stenlås, and Gribbe 2010). As put in the government's national security declaration from 1976, 
... future wars and crises may to an increasing extent and in other ways impact the entire society and its population. Total defence shall therefore be perceived as part of society and the societal development.

(Government of Sweden 1976 [emphasis added]).

The public investigation report preceding this government bill even stated that in the 1970s, total defence was no longer to be seen as an exceptional governmental practice, organised exclusively for the protection of territory. Rather, "relations within states" were to be "given far more consideration in security policy assessments", since

[i]n a situation when people do not perceive the threat of war as impending ... eyes are turned towards domestic issues. Citizens' loyalty tends to change from a territorial orientation, with the own state as means to defend against external threats, towards a more functional orientation towards one's work, environment, physical surroundings, etc. ... It is obvious that even if physical security in the form of defence against invasion still plays an important role in the perception of security, it now also contains different elements of economic and social security. ... [F]aith in society ... is a primary condition for the will to protect that society. It is important that fundamental values about societal concerns are shared.

(SOU 1976, 184-85 [emphasis added]; see also Ministry of Defence Sweden 1976)

Indeed, defence professionals at the time saw society as constituting at once 'the 'asset' which total defence must be able to protect against external threats, and the 'resource' from which to draw in order to produce such a defence" (Pettersson 1977, 8, 21).

By giving such prominence to the societal "organism", Swedish total defence architects created (at least the appearance of) a kind of proto-societal security. Despite this appearance, however, security policies during the Cold War never de facto broadened the scope of threats towards society as such, and never explicitly moved beyond the strict peace-to-war scale and the capacity to respond to an "external attacker" (Ministry of Defence Sweden 1981). Even though official discourse had made occasional reference to the potentiality of "surprise acts of terror bombings" in the past (SOU 1944; Von Konow 1961, 159), this had been done strictly with reference to military air raids against civilians, and the military threat was typically classified as either (a) mass attack or multi-front invasion, (b) limited attack or singlefront invasion, or (c) surprise attack. ${ }^{9}$

Towards the late 1970s and early 1980s, however, defence analysts and security advisors began suggesting that society's openness and rapid technological development heightened sensitivity to disruptions, had increased 
vulnerabilities, and made infrastructures an increasingly attractive target for aggressors. Putting society at risk of being "wiped out by smaller attacks", antagonists were increasingly prepared, it was argued, to "threaten or extort without needing to resort to military power instruments", for instance, by means of "sabotage and terrorism" (Pettersson 1977, 70; see also Sondén 1984). From the mid-1980s and onwards, actors from the civil- and economic-defence branches started converging around claims such as these, including the perceived need to fundamentally alter the official threat and risk spectrum and shift focus from external invasion to various threats "in our midst". Total defence, or more accurately, civil defence and its central scope and aim concerning what to counter, was about to become reconfigured during a period of significant bureaucratic and political reform.

\section{Total defence in transformation}

What follows is a detailed analysis of the transformation of Swedish total defence after the Cold War, that is, of how and when the first organised attempts were made at reconfiguring security practices away from the military organisation to a more fragmented system for crisis management and counterterrorism, and how this was done first and foremost by imposing new and other forms of threats and risks towards society. In particular, this section illustrates how such a process took place in the context of civil defence, not merely through formal political and legal reforms in this area, but also through intra-agency and ministerial struggles aimed at challenging the established logic of total defence. Gradually, new threat discourses and security practices were introduced, often in tandem with new platforms for academic research and knowledge production in these areas.

Specifically, this section explores the following questions: when and where were discourses and practices related to "crises" and "terror" officially (and non-officially) introduced for the first time? By whom, and under which political and bureaucratic conditions? What was said to necessitate a reconfiguration and rebranding of total defence? Departing from the sociohistorical context of total defence and war preparedness, two general phases can be identified in the Swedish security and defence sector after the Cold War: one of rethinking (late-1980s to mid-1990s), followed by one of restructuration (mid-1990s to early-2000s).

\section{6-1998 - challenging the logic of civil defence}

In 1985, a government bill was adopted by the parliament which proposed the establishment of the Swedish Emergency Management Agency (ÖCB) the following year. This meant that, for the first time, Sweden would have an independent agency singularly responsible for coordinating the many 
non-military functions of the defence apparatus, with particular emphasis on aspects related to civil protection and economic planning (Artéus and Fältström 2011, 64; Government of Sweden 1985). ÖCB was supposed to serve total defence in a role of overseeing, planning, training, and evaluation of relevant actors, and thereby, it was hoped, make cooperation between its civil and military parts more organised and cost-efficient. After extensive debate between bureaucrats, lawyers, and politicians, it was decided that despite its role as central coordinating agency, ÖCB should not be led by a "civil supreme commander" equivalent to that of the armed forces. Rather, the so-called "responsibility principle" should continue to be in effect, which meant that whoever was operationally responsible for a certain societal function in peacetime should be prepared to be so also in times of war.

As a newcomer in the field, ÖCB and its first director Gunnar Nordbeck began asking far-reaching and, according to some, uncomfortable questions whether civil defence should be only about "war rationing and misery" or if it should also include other forms of peacetime incidents (ÖCB 2002, 10). Ideas of vulnerability in societal infrastructures (which were not new, but had been present in defence policies for decades) were now brought to the fore as a way to place emphasis on security issues beyond invasion. An ÖCB "perspective study" from 1989 with the task of outlining the future of civil defence was one of the earliest official texts to genuinely consider "nonmilitary threats" such as "sabotage against vital nodes in society" (ÖCB 1989, 8-9). It claimed that the preparedness measures currently in place, in a period of international disarmament, were "far too schematic and in need of nuance". The text further stated that "military and non-military threats were bound to become interlaced" (11).

ÖCB was a young and untested agency, and also lacked the legal mandate to force change upon other actors. It was to act as the central conductor and coordinating agency, but still, according to the constitutional system in Sweden, remain hierarchically equal with all other government agencies. Therefore, in their everyday interactions with other civil defence actors, ÖCB's director and so-called "BIS-ambassadors" were obliged to work through "intelligence and charm" and with "social rather than coercive methods" when pushing for increased attention to new threats and risks (ÖCB 1989, 33). "We wanted the agency to be primus inter pares ['first among equals'] ... so the difficult challenge was to simultaneously lead and not lead", as put by a former ÖCB official. ${ }^{10}$ Sweden's constitutional system of strong and autonomous agencies still exists; indeed, all of the ÖCB's institutional successors have been obliged to similarly draw on social and political forms of capital, instead of explicit legal or constitutional powers.

In 1992, the second ÖCB director Gunilla André began imposing a more modern ${ }^{11}$ take on the "terrorism threat" in a string of newspaper debate pieces, as well as internally in the agency. "Everything suggests that the risk of direct warfare against Sweden should be minimal while the risks of crises 
are large", she wrote, and so "[t]hreats such as nuclear accidents, large-scale migration, and acts of terrorism are part of the picture" (André 1992a; see also 1992b; and Eneberg 1992). She has commented retrospectively that:

Suggestions to widen the threat-scale did not resonate with the ministry of defence at the time, however. We were supposed to plan for a war situation, nothing else. Even if I, a loyal servant to the state, respected this policy stance, I could not help but bring up societal threats in a wider perspective during the politician meetings that ÖCB arranged. It just so happened that many members of parliament shared my thoughts, which eventually resulted in several parliamentary motions on this theme.

(ÖCB 2002, 38)

After a series of efforts by ÖCB to influence key decision makers - itself an unorthodox move for a state agency - a committee initiative in parliament finally pushed the government to appoint the so-called "Threat and Risk Investigation" which ran between 1992 and 1995 (SOU 1995). Its final report sketched an image of society under threat by new and emerging phenomena such as mass migration and asylum seekers, severe disruptions in power and water supply, major urban accidents or attacks, and other threats perceived to be in a "grey area" between war and crime. Its head investigator, Eric Krönmark, a former defence minister and member of the Conservative Party, had the explicit vision of merging the areas of internal policing and external defence which in his opinion were far too disjointed and should rather share resources and equipment. Controversially at the time, his investigation team "looked into options of designing a kind of "national guard', which were not received favourably". 12 This was voted down since the domestic use of the army had been regarded as a "politically untouchable" question in Sweden ever since the 1930s, when a clash between union protesters and the army left five civilians dead and caused major public protests, especially from the working classes.

"When [Krönmark's] investigation report was handed over to the thenrecently appointed defence minister Thage G. Peterson, who had held several cabinet positions for many years, he explained that this was the most important report he had ever received", the former ÖCB director recalls (ÖCB 2002, 38). Peterson himself makes clear, however, that he "had no support" for politically implementing these ideas in the 1990s, and "regrets not picking a fight":

Time was not ripe for changing the view on what constituted threats and risks in society. When I began talking about the necessity of terrorism preparedness ... these issues were not taken seriously. Many shook their heads and argued that national defence should not meddle with these issues ... Developments in recent years seem to have proven me right, though, so perhaps I was ahead of my time.

(ÖCB 2002, 56) 
Indeed, to propose changes of the Swedish national security strategy tends to be a slow process, and again, largely due to reasons of constitutional design. The "defence resolutions" presented by the government every fifth year are supposed to dictate the overall direction of defence priorities for the next half a decade, thereby virtually framing what should be at all thinkable and doable in the area of security. Based on a 10-15 year "planning horizon", these resolutions are far from revolutionary, mainly for two reasons. First, resolutions are required to draw on the recommendations of all securityrelated government agencies. As mentioned, the constitution gives Swedish agencies authority and elbowroom, as well as relative autonomy and independence from the ministries under which they are sorted. Second, resolutions must also draw on the recommendations of the defence commissions. Constituted by representatives from all parties of parliament, ${ }^{13}$ the defence commissions formulate policy suggestions that are more or less ensured to gain broad political support, and their reports tend to largely reflect what eventually becomes voted into legislation (Lundin and Stenlås 2010, 16). Therefore, if one were to suggest a radical redirection of security policy, one would need to convince at once the government, multiple agencies, and the parliament (as represented in the current defence commission).

Reformists during the early 1990s were thus unsurprised that it took almost a decade for their thoughts and ideas to be considered in actual policies and legislation. Although ÖCB officials had observed and anticipated societal and international developments for some time, they understood that "making changes is like altering the course of a steamer: it takes a long time and the room for manoeuvre is limited". The agency system is usually slow to react, a key reformist has noted: "the [Berlin] wall fell already in 1989, but ÖCB survived all the way up until 2002" ${ }^{14}$ Similarly, the defence commission had also assessed changes in the "international security environment" during the mid- to late-1990s, and anticipated its "widening" effect on security discourse (Ministry of Defence Sweden 1996a, 1998), but without any immediate effect on practice.

It is interesting to note how many of the new threat constructions and reform ideas during this period came not from professional politicians, but to a large extent from the everyday settings of bureaucrats operating in the civil defence area. Here, the challenge for agency staff was about pushing bureaucratic knowledge into political processes and state commissions. For political defenders, on the other hand, the challenge was about blocking such moves by insisting on the continued policy relevance of conventional geopolitical threats. From a long-term perspective, ÖCB's peculiar lobby efforts as well as the Threat and Risk Investigation's final report were arguably of key importance, however, since they effectively opened up avenues for the state, and particularly the ministry of defence and parliament, to think, talk, and write about new (in)securities.

Indeed, parts of the arguments presented initially in the Threat and Risk Investigation were picked up and inserted into the subsequent defence resolutions and government bills around 1995, namely, the two interlinked 
propositions on "renewing total defence" (Government of Sweden 1995; 1996a; see also Ministry of Defence Sweden 1995c), and another one on the "readiness against severe strains on society in peacetime" (Government of Sweden 1996b; see also Ministry of Defence Sweden 1996b). When passed, these reforms led to the discontinuation of large parts of the military organisation as well as a shift of budget priorities according to the new security policy organised not around war, but "peacetime strains". Although the logic and scope of total defence was challenged by ÖCB as early as 1989, it is not until the 1995-1996 propositions that we can see the so-called "widened security definition" become declared as government policy.

Alongside the above-mentioned reforms, the ministry of defence was further occupied with carrying out the mandatory EU adaptations of domestic policy since Sweden had just become a full member state in 1995 (Ministry of Defence Sweden 1995b, 1999). This meant responding to the so-called "Petersberg tasks" and the 1997 Amsterdam Treaty (later to formalise into the EU Common Security and Defence Policy) which, among other things, broadened the practical military scope to include crisis management in peacetime. Sweden had also recently joined NATO's Partnership for Peace (PfP) programme, and the ministry of defence focused initially not on military-to-military training, but rather on policy discussions on disaster planning and response. Reformists from within the Swedish defence sector working with the PfP and EU adaptations in the 1990s saw these engagements with international institutions as windows of opportunity for further shifting professional mindsets at home towards a "beyond-military" disposition. Indeed, they saw the demand for necessarily new forms of thinking and doing security - ways which were not fixed along a war-to-peace scale, but which recognised that whatever laid beyond territorial defence was not simply peacetime emergency planning or uniformed blue-light personnel, but something radically different concerning an evolved form of antagonism aimed directly at citizens, democracy, and rule of law (KKrVA 1998, 15). Overall, it can be concluded that the acquisition of EU-level (or otherwise "international") forms of knowledge, authority, and expertise by Swedish bureaucrats had an accelerating and legitimating effect on the ongoing reforms at home (see also Kauppi and Madsen 2013; Bigo 2016).

During the implementation of the 1990s reforms, bureaucrats, legislators, as well as academics became increasingly aware of the need for an updated conceptual and terminological toolbox. As new agency guidelines, policy proposals, and legal drafts had to be written, new explanation models and threat descriptions were in demand. In order to fill the "knowledge gap" created to a large extent by the end of the Cold War, ÖCB was mandated to identify emerging Swedish scholars in the area of defence and security studies, and to distribute around SEK 25 million annually to fund their research environments (ÖCB 2002, 35). ÖCB targeted scholars in their vicinity who they hoped could produce concepts and models "that would describe the new threats". ${ }^{15}$ At this stage, two persons outside of ÖCB played key roles. 
First, Christina Weglert, a former agency executive who had moved to head of department at the Swedish Defence University (FHS) was early to notice the demand for "new ways of thinking about the training and exercising of military personnel". Seeking to offer practitioners "a different perspective" from the intersection of the civil and military knowledge domains, she strongly supported the creation of a new research team at her department (ÖCB 2002, 58). Second, security and crisis management scholar Bengt Sundelius - already a familiar face to many Nordic defence practitioners in the 1990s - came to be the central figure around which new forms of functionalist security research was to be mobilised. Dissatisfied with the general stagnancy and inflexibility of his former employer (Swedish Defence Research Institute (FOI)), and seeking closer proximity to practitioners than what could be offered by his current employer (Uppsala University), Sundelius searched for a different environment somewhere in-between research and practice where he could gather his network of young crisis management scholars. "Simply put, Bengt had the scientific bits, Christina had the facilities and administration, and I sat on the money", as described by a former ÖCB official. ${ }^{16}$ The Center for Crisis Management Research and Training (CRISMART) was founded in the end of the 1990s and emerged as the leading research hub for crisis studies in Sweden. Their primary goal, according to Sundelius, was to "produce a cadre of competent co-workers" in this growing area of practice. Responding directly to ÖCB's call for new applicable security models, they conducted "problem-oriented" and "policyrelevant" studies at the intersection of research and practice, and offered tailored exercises and training courses for state officials and agency personnel. Over the coming years, this team of self-proclaimed "pracademics" in and around CRISMART managed to establish close relationships with the new generation of security practitioners as well as with officials in the upper segments of the state. These relations enabled some scholars to take up key positions as "experts" also outside of academia, in both public and private organisations, while others remained multi-positioned and moved between various roles and responsibilities in and beyond universities.

This process is a prime example of how academic and political discourses of (in)security, in certain times and places in recent history, have been able to emerge in parallel, co-informing and reinforcing one another into a distinct category of knowledge. One may compare, for instance, Swedish security scholars during the 1990s with the early years of the RAND Corporation, when a small group of researchers set out to explain the logics of nuclear war in the 1950s and 1960s:

With no empirical evidence to support their findings (no nuclear war had been fought!), the group developed a thought-provoking and immensely influential view of how nuclear strategy should be performed. From the models it developed, policy advice was deducted and policy formed. ... The RAND people not only were good at producing 
scientific knowledge, but also had efficient channels for transmission of their ideas to practitioners - including politicians ... Many in the US government felt that 'it added scientific legitimacy' ... to listen.

(Berling 2011, 391)

ÖCB presumably had similar ideas about the research activities they funded, hoping that it would "close down controversies in the political realm" and that the scientific products, facts, models, and approaches that were generated could be "mobilised strategically ... as 'weapons' in political struggles" (393) in their efforts to secure their particular version of post-Cold War security as the most legitimate one.

Not only can security research close down controversies for bureaucrats and politicians that may have particular goals in mind, but, at times, researchers may also themselves be opportunistic and tailor their theoretical work to make it "practical" for government. As Bonditti and Olsson (2016, 244) show, this was the case in the early days of terrorism research when some scholars linked their "theories on terrorism developed in the context of 'scientific publications' or other 'academic settings' to the particular interests of security professionals". In Sweden, certain scholars similarly "reorganised security knowledge" around new threats or crises, thereby "opening up a space of indeterminacy" between defence and policing, between crime and war (242), a space in which they automatically became the new generation of "experts" (see also Stampnitzky 2013; Herman and O'Sullivan 1990).

\section{8-2008 - agency reforms for crisis management and counterterrorism}

Around the turn of the millennium, major reforms were again planned. This time, however, they would come to have a more substantial effect on the agency system. A carefully drafted ÖCB report in 1998 entitled "The new security" again helped entice government officials to appoint a commission, this time the so-called "Vulnerability and Security Investigation". Former Centre Party cabinet minister and Nordic Council secretary Åke Pettersson was selected as head investigator by the ministry of defence in 1999, and his team consisted of key figures from across the civil defence sector, among them Sundelius and leading reformists from within ÖCB. For two years, they conducted over 50 case studies on critical infrastructure vulnerabilities, and in May 2001, Pettersson presented their final report called "Security in a new era" (SOU 2001). In it, they effectively managed to incorporate the plethora of bureaucratic struggles and political decisions from the past 15 years, leading to the major proposal to discontinue ÖCB, along with the idea of civil defence altogether, and replace it with a new crisis management agency.

More fundamentally, this investigation - together with the defence commission reports written alongside it which produced similar conclusions 
(Ministry of Defence Sweden 2001b, 2001a) - meant that the threat of invasion was effectively written off in favour of not just "peacetime strains", but crises related to asymmetrical attacks, major accidents, natural disasters, and other incidents to be captured by the proposed "all-hazards" approach. This marked the beginning of a "strategic timeout" for the traditional total defence model. As put by Pettersson, "this was a time when we did not experience that many threats, but we did however feel the need to guard ourselves against what has come to be called terror attacks" ${ }^{17}$ Co-investigator Bo Riddarström from ÖCB claimed that they wanted to give asymmetrical threats just as much, if not more, attention as external threats: "Indeed, anyone with merely a hunting rifle, knowing where to go, could shut down Sweden's power supply for at least three months". ${ }^{18}$ This investigation report in other words signified a key moment in the transformation of Swedish security, as suspicions began to shift from extraterritorial enemies to internal antagonists, and as a wider range of threats and risks shifted from being a peripheral priority at ÖCB to becoming the very core of the new agency's assignments.

The new crisis management agency was to continue like ÖCB in a noninterfering, overseeing, and coordinative role. This required new ways of "exploiting society's collective resources" for security purposes, it was argued, and so the responsibility principle already present in total defence planning was complemented by the similarity ${ }^{19}$ and proximity ${ }^{20}$ crisis management principles (SOU 2001, 18, 25). The agency was also to focus on so-called public-private partnerships (PPPs) in the area of security and infrastructure protection, since critical infrastructures had become increasingly outsourced in the early 2000s (not only in Sweden but also in most Western societies). Disaster planning and crisis management was thus to be seen not as an exclusive government matter, but - just as per old defence ideals - as concerns also involving local, regional, and private actors, making it into a project driven by and for the totality of society. Here, the SOU report hinted at a kind of "reversal": it suggested that the (now much smaller) armed forces were to aid public and private organisations in managing disruptions in IT, communications, water and power supply, flooding and dam failures, mass migration of refugees and asylum seekers, pandemics, and terrorist attacks - rather than the reverse situation of civilians aiding the defence establishment, which had been the case during the Cold War era (252).

Despite being well received upon its publication in May 2001, when the subsequent government bill for the "continued renewal of total defence" was to be drafted later that summer (Government of Sweden 2001), the SOU report was surprisingly underutilised in the early versions of the bill. However, when the final proposition was eventually presented to parliament on September 26 (that is, only a few weeks after the 11 September 2001 terror attacks in the United States), it suddenly contained large chunks of text pasted in from the SOU report. ${ }^{21}$ In other words, despite stemming from a long and careful process during the late 1990s of preparing the discontinuation 
of civil defence in favour of a new crisis management agency, the first major step in 2001 to carry out these reforms was in fact more or less reactionary to the events in the United States. "9/11 'saved', if you will, Åke Pettersson's vision", according to Sundelius, who had followed these reforms closely, as the terrorist attacks pushed decision makers to reconsider their positions, thereby speeding up the turn towards crisis management and counterterrorism practices in Sweden.

Indeed, in anticipation of the reforms to come out of the SOU report, ÖCB officials and their new allies from academia began intensifying discussions regarding how to relabel total defence. However, since a more or less established operational definition of total defence was already in place in up to 150 different statutes and legislative acts at the time, this was no easy task, and many practitioners were explicitly against a reformulation of the defence discourse. Nevertheless, Sundelius was one of those who tried to rework the existing definition, namely by writing a report for the thendefence commission in which he suggested the terminology "societal defence". What he described as "societal defence", however, still seemed more or less identical to the total defence model of the past, but now with a stronger emphasis on Swedish society's embeddedness in an international and transboundary context, and more importantly, it encompassed how to counter the new threats and vulnerabilities supposedly stemming across borders (Sundelius 2001a, 8-9).

Later that year, following violent protests during the EU Summit in Gothenburg in June 2001, that policy paper was rewritten into a debate article for Sweden's largest newspaper Dagens Nyheter in which it was phrased, more bluntly this time, that Sweden was in need of a "societal defence against terrorists". In passing, it was suggested - just as had been done by Krönmark a decade earlier - that for such a revamped non-territorial defence to work, the police and military organisations should be able to cooperate more closely and share equipment to counter non-state antagonists (Sundelius 2001b). "Societal defence" was received with mild indifference politically and never took off in official discourse. Instead, Sundelius and his colleagues developed and further specified their idea of "functional" (as different from "territorial") security by starting to name it "societal security". Incidentally, their Danish colleagues of the so-called Copenhagen School of security studies (or more precisely, Ole Wæver at the Copenhagen Peace Research Institute) had already in 1993 written on the "concept of societal security" (see also Rhinard, this volume). After some debate between the two in the late 1990s, Wæver supposedly had "handed over" this concept to Sundelius and allowed him to keep developing it around a functionalist rather than identity-centred definition. ${ }^{22}$ In the early 2000s, Sundelius and others scholars around the CRISMART team thus came to appropriate and rework the notion of societal security, strip it of Wæver's original definition, and promote it as a more open-ended practical concept and work terminology to be used by agencies and policymakers and even industry. After the 
events of 9/11, advocates of societal security envisioned it as the new Nordicperhaps even European ${ }^{23}$ - sibling-concept to "homeland security" which was being simultaneously developed and put to work in the United States around 2001-2003.

Another key detail from the 1999 to 2001 reform period was the two study trips organised between the Swedish SOU team and a Norwegian team working in parallel on reforming practically the same policy area. The purpose of the trips between Stockholm and Oslo was to exchange and acquire ideas, specialist knowledge, and policy blueprints from both civil and military organisations concerning how to modernise, and eventually move away from, the total defence heritage they both shared (NOU 2000, 22, 242, 321). The final publication by the Norwegian investigation team - "A vulnerable society: Recommendations for the security and readiness of society", published in July 2000 after only ten months in the pipeline - therefore had several similarities with the Swedish report, not least in how they both saw the increased openness and technological evolution of post-Cold War Nordic societies as producing a wider threat spectrum, ranging from natural hazards to terrorist attacks (6-7). The Norwegians also agreed generally on how to organise against such threats, namely, by establishing a new coordinative crisis management agency (DSB), and by implementing the same organisational principles (responsibility, similarity, and proximity). Notably, however, Norway decided to organise this area under the ministry of justice rather than defence, and also chose from the very outset to refer to this kind of work as "societal security", or samfunnssikkerhet (see Morsut, this volume). In Sweden, the equivalent term of samhällssäkerhet in fact never cemented itself as the main umbrella term in the same way, and the new crisis management agency was to remain under the ministry of defence instead of migrating to ministries of interior or justice.

In 2002, a second government proposition building on the previous year's Vulnerability and Security Investigation was passed in parliament, leading to the discontinuation of ÖCB, and the establishment of the new and slimmer Swedish Emergency Management Agency (KBM) (Government of Sweden 2002, 43-44). In addition to the recommendations of Pettersson's SOU team, KBM was to continue identifying emerging security scholars and administer its own research funding scheme (now with a more than doubled budget of SEK 60 million per annum). Although KBM wanted to link up security practitioners with private industries and emerging technological producers, it was beyond the agency's scope to directly fund private actors since recipients had to be based at academic institutions. They therefore retained focus on setting up and funding new research environments from which a supply of future professionals could be generated. Sundelius was now leading this enterprise himself from within KBM, as he had acquired the position of agency research director, and continued to fund research in line with the CRISMART credo of linking together academia (and academics) with practice (and practitioners) (51, 65-66; KBM 2008, 36-37). 
Hence, KBM funds went into establishing the new Center for Asymmetric Threat Studies (CATS) at the Defence University in 2004, making it Sweden's first "government think-tank" dedicated to the field of terrorism studies. Like CRISMART, CATS produced classified policy papers for cabinet offices and arranged exercises with civil servants and the government. ${ }^{24}$ Their scholars also engaged with mainstream and social media as self-proclaimed "terrorism experts", with a tendency to express particularly opinionated views when it came to so-called "Islamic terrorism" (Flyghed 2005, 175-177). The precursor to CATS, called the Center for Information Operational Studies (CIOS), had in fact been an analytical team working under the government since 1998 with intelligence and information warfare. However, after the events of 9/11, KBM's research department viewed terrorism studies as a top priority and decided to reconfigure CIOS, transfer it to the Defence University, and provide it with an annual "research environment support grant" to ensure its permanence and its capacity to attract leading national and international terrorism scholars. "[KBM] had the mandate to fund research, but not the experience", Sundelius has claimed, not denying that he was able to allocate funding rather freely to his colleagues in Sweden. ${ }^{25}$ Research directors of this kind might be compared to an impresario in the theatre world, i.e. a director-figure who finances, facilitates, and organises plays and concerts - those who "by their decisions [could] mould the taste of an age" (Bourdieu 1969, 91). Similarly, Mills saw this type of entrepreneur figure as increasingly common in social scientific research environments: those who are discontent with the old-fashioned professor roles and "ordinary" academic careers, and those who instead "set up on the campus a respectably financed research and teaching institution, which brings the academic community into live contact with men of affairs" (Mills 2000, 98, 103).

Alongside the establishment of CATS, Sweden's counterterrorism policies and strategies also began to crystallise. Between 2004 and 2006, the defence commission authored a long-term security strategy which not only oriented priorities around the new agency structure but also implicitly positioned Sweden as an ally in the so-called "global war on terror", thereby breaking with the notion of "non-alignment" from the total defence era: "Shared vulnerabilities and transgressive threats means that Swedish and international interests coincide to an increasing extent ... In today's world, it is just as important to secure flows [of things and people] as it previously was to protect territorial borders" (Ministry of Defence Sweden 2006, 11). Domestically, a state investigation sparked by the 9/11 events resulted in a report in 2003 on Sweden's "preparedness against terrorism" (SOU 2003). The report proposed far-reaching policy ideas such as new terrorism legislation, a radical hybridisation of military and police organisations, and a substantially expanded mandate for the Swedish Security Service (SÄPO) - the actor with central operational responsibility in the area of counterterrorism. 
Few of these suggestions became reality when government bills were subsequently drafted, however. Instead, since around 2005, SÄPO has been responsible for convening the Swedish Counter-Terrorism Cooperation Council (SÄPO 2019b) which gathers 15 different agencies, including the armed forces, coastguard, and migration agency. Within this council, moreover, the National Centre for Terrorist Threat Assessment (NCT) is a permanent working group staffed by personnel from SÄPO, the National Defence Radio Establishment (FRA), and the Military Intelligence and Security Service (MUST). The NCT "produces long and short-term strategic assessments of the terrorist threat against Sweden and Swedish interests" and presents strategic reports to various government offices (SÄPO 2019a). Similar to the US Department of Homeland Security's "National Terrorism Advisory System", the NCT produces an annual "threat level scale" with regard to terrorism, with an arbitrary range of "No threat (1), Low threat (2), Elevated threat (3), High threat (4) and Very high threat (5)" (SÄPO 2018).

Finally, following yet another public investigation between 2006 and 2007 (SOU 2007), KBM was eventually merged in 2008 (after only six years in existence) with the Rescue Services Agency (SRV) and the Psychological Defence Board (SPF) into the currently operational Swedish Civil Contingencies Agency (MSB). The MSB agency continued to promote an "allhazards" and "whole-of-society" approach to security to targeting the full spectrum of environmental and human-induced threats, risks, and disasters (Lindberg and Sundelius 2012), and remained centrally responsible for all things security-related, including actor coordination, training, evaluation, and research funding (again with a doubled budget of SEK 120-140 million per year) as well as international cooperation with the EU and DHS. Notably, however, even after the creation of MSB, societal security was not established as the official terminology or dominant discourse in the Swedish field - despite being proposed as such by Sundelius in 2004 (SOU 2004), who had now advanced in rank again to become senior agency advisor. Rather, societal security came to be used interchangeably, depending on actor and context, with terms like civil contingencies, crisis management, emergency preparedness, and civil security.

\section{Conclusion}

In retrospect, it perhaps comes as little surprise that the notion of "societal security" in Sweden emerged in the historical context of Swedish total defence, and in the bureaucratic and political structures associated with that conceptual approach. The modus operandi of total defence was arguably always about the security of society (perhaps even more so than of territory, since Sweden had insisted that its "total defence" was purely "defensive", i.e. designed for deterrence rather than actual combat). With its emphasis on societal values, citizen participation, holistic logics, and the fundamental interdependence of infrastructure and security-related functions, total 
defence laid the organisational and cultural groundworks for post-Cold War approaches to security. Then, just as now, central coordination and planning of security practice had to be balanced against a logic of massparticipation and responsibilisation. Then, as now, "society" became acted upon and perceived as at once the "asset" to protect and "resource" from which to draw.

What changed drastically after the Cold War was rather the sociopolitical and technological makeup of that society, as well as its general position in a broader transnational context. In fact, debates and reforms during the 1990s came to largely concern what threatened the notion of a Swedish society, and how such threats should be countered. This chapter thus centred its analysis on how authority was mobilised by bureaucratic, political, and academic actors to help construct a new post-Cold War "enemy", and determined how, by whom, and with what effects certain emerging "asymmetrical", "internal" and "transgressive" threats and risks became uttered, imposed, and negotiated into practice.

Indeed, a key moment in this struggle was the mid- to late-1990s. During these years, the perspectives of total defence traditionalists in the Swedish parliament, government, and ministries were replaced by those of civil defence reformists and emerging security experts who together managed to co-produce and co-legitimate new forms of security knowledge and authority. As agency officials were granted the mandate to establish and fund new research environments, these platforms came to produce research(ers) that, in turn, supported their worldview and dampened any major political controversies. A different (but perhaps not entirely new) kind of professional cadre with regard to defence, security, crisis management, and counterterrorism began to emerge around the turn of the millennium. The Swedish post-Cold War period is thus a pertinent and revealing example of the familiar phenomenon of academic and policy interests and forms of "security expertise" intermingling, feeding into each other, and influencing the transformation of certain vital state practices.

\section{Notes}

1 Societal security, as it is commonly referred to by practitioners today, is in other words not the same product as the theoretical concept with the same name coined initially by the Copenhagen School (Wæver 1993) from which various attempts at "broadening" the meaning of security in IR have departed (Ilgit and Klotz 2014; Roe 2005; Saleh 2010; Theiler 2003; see also Rhinard, this volume).

2 All interviews conducted between March 2017 and January 2018. Translations of transcripts and other primary sources from Swedish to English have been undertaken by the author.

3 The analysis focuses on the restructuration of the Swedish agency system since the constitutional design in Sweden (as similar to Finland, but different from most other Nordic and European states) provides agencies with a strong and autonomous role, relatively independent from the government ministries/ministers under which they are sorted (Lundin and Stenlås 2010, 16). 
4 Interview with Jan Lundberg, strategic analyst at ÖCB, KBM, and MSB.

5 Interview with Peter Lagerblad, former director of the Defence Commission and agency official at ÖCB.

6 Interviews with Bo Richard Lundgren, former agency official at ÖCB and KBM, and Bo Riddarström, former agency official at ÖCB and co-investigator of SOU 2001:41.

7 The private sector was further engaged in war planning through the notion of $K$-företag. During the so-called "Swedish Boom Years" of "public-private cooperative ventures" in several infrastructural areas (Lundin and Stenlås 2010, 10-15), legislation was drafted that would come to eventually classify tens of thousands of private infrastructure companies, banks, insurance firms, and arms producers, as "war companies", giving them special status as crucial actors for the Swedish defence effort.

8 Interviews Lundberg, Riddarström, and Lundgren.

9 Interview with Gunnar Holmgren, former agency official at ÖCB and coinvestigator of SOU 1995:19.

10 Interview Lagerblad.

11 A temporary "terrorism law" had been introduced in 1973 as a response to the attacks at the 1972 Munich Olympics. This law then became transferred between different legal statutes, gradually redefined and phased out, and eventually removed in the late 80 s.

12 Interview Holmgren.

13 However, both the Left Party and the far-right Sweden Democrats have previously been excluded from the defence commission.

14 Interview Lundgren.

15 Interview Riddarström.

16 Interview Lundgren.

17 Interview with Ake Pettersson, head investigator of SOU 2001:41.

18 Interview Riddarström.

19 Organisational routines and structures during crises should to the largest extent possible resemble those in a normal situation.

20 Any attack, accident, or incident should be managed as close to its source as possible.

21 Interview with Bengt Sundelius, senior agency adviser at MSB and founder of CRISMART.

22 Interview Sundelius.

23 On the cross-over notion of "European homeland security", see the works of Rhinard and Boin (2009), Cross (2007), and Kaunert et al. (2012).

24 Interview with Lars Nicander, director of CATS.

25 Interview Sundelius.

\section{References}

André, Gunilla. 1992a. 'Krisberedskapen Allt Viktigare'. Svenska Dagbladet, 9 February.

1992b. 'Civilförsvaret Bristfälligt Utrett'. Dagens Industri, 1 April.

Artéus, Gunnar, and Herman Fältström. 2011. Totalförsvaret under Sveriges kalla krig. Stockholm: Swedish Defence University.

Berling, Trine Villumsen. 2011. 'Science and Securitization: Objectivation, the Authority of the Speaker and Mobilization of Scientific Facts'. Security Dialogue 42 (4-5): 385-97.

Bigo, Didier. 2016. 'Sociology of Transnational Guilds'. International Political Sociology 10 (4): 398-416. doi:10.1093/ips/olw022. 
Bigo, Didier, and Médéric Martin-Mazé. 2014. 'D4.1 Report on Theory and Methodology for Mapping of Societal Security Networks'. SOURCE - Virtual Centre of Excellence for Research Support and Coordination on Societal Security (EU FP7).

Bonditti, Phillippe, and Christian Olsson. 2016. 'Violence, War and Security Knowledge: Between Practical Theories and Theoretical Practices'. In T. Basaran, D. Bigo, E-P Guittet, and R.B.J. Walker (eds.), International Political Sociology: Transversal Lines, 228-253. Abingdon: Routledge.

Bourdieu, Pierre. 1969. 'Intellectual Field and Creative Project'. Information (International Social Science Council) 8 (2): 89-119. doi:10.1177/053901846900800205.

Cross, Mai'a K. Davis. 2007. 'An EU Homeland Security? Sovereignty vs. Supranational Order'. European Security 16 (1): 79-97. doi:10.1080/09662830701442410.

DSB. 2019. 'Om DSB'. Direktoratet for Samfunnsikkerhet Og Beredskap. www.dsb. no/menyartikler/om-dsb/.

Eneberg, Kaa. 1992. 'Krisen Hotar Skyddsrummen'. Svenska Dagbladet, 17 November.

European Commission. 2018. 'Secure Societies - Protecting Freedom and Security of Europe and Its Citizens'. Horizon 2020. https://ec.europa.eu/programmes/ horizon $2020 /$ en/h2020-section/secure-societies- $\%$ E2\%80\%93-protectingfreedom-and-security-europe-and-its-citizens.

Flyghed, Janne. 2005. 'Crime-Control in the Post-Wall Era: The Menace of Security'. Journal of Scandinavian Studies in Crimology and Crime Prevention 6 (1): 165-82.

FOI. 2013. 'Fokus Samhällssäkerhet: FOI och arbetet med samhällets säkerhet och trygghet'. Sweden: FOI.

Foucault, Michel. 2007. Security, Territory, Population: Lectures at the Collège de France 1977-78. London: Palgrave Macmillan UK.

Government of Sweden. 1976. 'Government proposition 1976/77:74 inriktningen av säkerhetspolitiken och totalförsvarets fortsatta utveckling'. 1976/77:74. Government of Sweden.

1985. 'Government proposition 1984/85:160 Om ledning av de civila delarna av totalförsvaret m.m.' 1984/85:160. Government of Sweden.

—. 1995. 'Government proposition 1995/96:12 Totalförsvar i förnyelse (Etapp 1)'. Government of Sweden.

1996a. 'Government Proposition 1996/97:4 Totalförsvar i Förnyelse (Etapp 2)'. Government of Sweden.

. 1996b. 'Government proposition 1996/97:11 Beredskapen mot svåra påfrestningar på samhället i fred'. Government of Sweden.

- 2001. 'Government proposition 2001/02:10 Fortsatt förnyelse av totalförsvaret'. 2001/02:10. Government of Sweden.

— 2002. 'Government proposition 2001/02:158 Samhällets säkerhet och beredskap'. 2001/02:158. Government of Sweden.

Herman, Edward S., and Gerry O'Sullivan. 1990. The Terrorism Industry: The Experts and Institutions That Shape Our View of Terror. New York: Pantheon Books.

Ilgit, Asli, and Audie Klotz. 2014. "How Far Does "Societal Security" Travel? Securitization in South African Immigration Policies'. Security Dialogue 45 (2): 137-155. http://sdi.sagepub.com/content/45/2/137.short.

ISO/TC 223. 2016. 'ISO/TC 223 Website'. www.isotc223.org.

ISO/TC 292. 2016. 'ISO/TC 292 Website'. www.isotc292online.org. 
Kaunert, Christian, Leonard Sarah, and Patryk Pawlak, eds. 2012. European Homeland Security. Abingdon: Routledge.

Kauppi, Niilo, and Mikael Rask Madsen. 2013. Transnational Power Elites: The New Professionals of Governance, Law and Security. Routledge Studies in Liberty and Security. London: Routledge.

KBM. 2008. KBM Från Början till Slut 2002-2008. Krisberedskap. Stockholm: KBM.

KKrVA. 1998. 'Handlingar Och Tidsskrift, 2/1998'. 2. Kungliga Krigsve tenskapsakademien.

Kronsell, Annica, and Erika Svedberg. 2006. 'The Swedish Military Manpower Policies and Their Gender Implications'. In P. Joenniemi (ed.) The Changing Face of European Conscription, 137-160. Aldershot: Ashgate Publishing Ltd.

Larsson, Sebastian. 2019. In the Name of Society: The Branding of Swedish Civil Security Technologies and Their Exclusionary Effects. London: King's College London.

Lindberg, Helena, and Bengt Sundelius. 2012. 'Whole-of-Society Disaster Resilience: The Swedish Way'. In David Kamien (ed.), The McGraw-Hill Homeland Security Handbook, 1295-1319. New York: McGraw-Hill.

Lundin, Per, and Niklas Stenlås. 2010. 'Technology, State Initiative and National Myths in Cold War Sweden: An Introduction'. In P. Lundin, N. Stenlås, and J. Gribbe (eds.) Science for Welfare and Warfare: Technology and State Initiative in Cold War Sweden. Sagamore Beach, MA: Science History Publications/USA.

Lundin, Per, Niklas Stenlås, and Johan Gribbe, eds. 2010. Science for Welfare and Warfare: Technology and State Initiative in Cold War Sweden. Sagamore Beach, MA: Science History Publications/USA.

Mills, C. Wright. 1956. The Power Elite. Oxford: Oxford University Press. 2000. The Sociological Imagination. Oxford: Oxford University Press.

Ministry of Defence Sweden. 1976. 'Svensk samhällsutveckling: Samhällets sårbarhet'. Ministry of Defence Sweden.

1981. 'Swedish Defence Commission 1981:1 Försvarskommitténs betänkade'. Departementsserien Ds 1981:1. Ministry of Defence.

. 1995a. 'Svenskt Totalförsvar'. Ministry of Defence Sweden.

1995b. 'Swedish Defence Commission 1995:28 Sverige I Europa och

Världen'. Departementsserien Ds 1995:28. Ministry of Defence Sweden.

. 1995c. 'Swedish Defence Commission 1995:51: Totalförsvarets utveckling och förnyelse'. Departementsserien Ds 1995:51. Ministry of Defence.

. 1996a. 'Swedish Defence Commission 1996:51: Omvärldsförändringar och svensk säkerhetspolitik'. Departementsserien Ds 1996:51. Ministry of Defence.

1996b. 'Swedish Defence Committee 1996/97 FöU5 Beredskapen mot svåra påfrestningar på samhället i fred'. Betänkande 1996/97 FöU5. Ministry of Defence Sweden.

1998. 'Swedish Defence Commission 1998:9 Svensk säkerhetspolitik i ny omvärldsbelysning'. Departementsserien Ds 1998:9. Ministry of Defence.

1999. 'Swedish Defence Commission 1999:55 Europas säkerhet - Sveriges försvar'. Departementsserien Ds 1999:55. Ministry of Defence.

2001a. 'Swedish Defence Commission 2001:14 Gränsöverskridande Sårbarhet - Gemensam Säkerhet'. Ds 2001:14. Ministry of Defence Sweden.

—. 2001b. 'Swedish Defence Commission 2001:44 Ny struktur för ökad säkerhet'. Departementsserien Ds 2001:44. Ministry of Defence Sweden. 
2006. 'Swedish Defence Commission 2006:1 En strategi för Sveriges säkerhet'. Departementsserien Ds 2006:1. Ministry of Defence.

MSB. 2011. 'A Functioning Society in a Changing World: The MSB's Report on a Unified National Strategy for the Protection of Vital Societal Functions'. Swedish Civil Contingencies Agency.

NOU. 2000. 'NOU 2000: 24 Et sårbart samfunn: Utfordringer for sikkerhets- og beredskapsarbeidet i samfunnet'. NOU 2000: 24. Government of Norway.

ÖCB. 1989. 'Civil Beredskap Inför Framtiden'. Perspektivstudie. Stockholm: ÖCB.

2002. Från Slutet till Början: Historien Om ÖCB Juli 1986 - Juni 2002. Stockholm: ÖCB.

Palmblad, Samuel. 2005. Kalla Krigets Kronoberg: Ett Län Och Dess Beredskapsplanering - En Del Av Vårt Kulturarv. Sweden: Smålands Museum.

Pettersson, Lennart. 1977. Det Sårbara Samhället. Stockholm: Rabén \& Sjögren.

Rhinard, Mark, and Arjen Boin. 2009. 'European Homeland Security: Bureaucratic Politics and Policymaking in the EU'. Journal of Homeland Security and Emergency Management 6 (1): 1-24.

Roe, Paul. 2005. Ethnic Violence and the Societal Security Dilemma. London: Routledge.

Saleh, Alam. 2010. 'Broadening the Concept of Security: Identity and Societal Security'. Geopolitics Quarterly 6 (4): 228-241.

Sandö, Carolina, and Alyson J. K. Bailes. 2014. 'Nordic Cooperation on Civil Security: The "Haga" Process 2009-2014'. FOI-R--3944--SE. FOI.

SÄPO. 2018. 'Assessment of the Terrorist Threat to Sweden in 2018'. SÄPO.

—. 2019a. 'National Centre for Terrorist Threat Assessment'. www. sakerhetspolisen.se/en/swedish-security-service/counter-terrorism/nationalcentre-for-terrorist-threat-assessment.html.

2019b. 'The Counter-Terrorism Cooperation Council'. www. sakerhetspolisen.se/en/swedish-security-service/counter-terrorism/the-counterterrorism-cooperation-council.html.

Sondén, Jan. 1984. Sveriges totalförsvar. Försvar i nutid 5. Folk \& Försvar.

SOU. 1944. 'Betänkande med förslag till civilförslagslag m.m.' SOU 1944:5. Government of Sweden.

—. 1976. 'Säkerhetspolitik och totalförsvar'. SOU 1976:5. Government of Sweden.

1995. 'Ett Säkrare Samhälle'. SOU 1995:19. Government of Sweden.

2001. 'Säkerhet i en ny tid'. SOU 2001:41. Government of Sweden.

2003. 'Vår Beredskap Efter Den 11:E September'. SOU 2003:32. Government of Sweden.

—. 2004. 'Informera om samhällets säkerhet'. SOU 2004:25. Government of Sweden.

- 2007. 'Alltid redo! En ny myndighet mot olyckor och kriser'. SOU 2007:31. Government of Sweden.

SOURCE. 2016. What Is Societal Security? www.youtube.com/watch?v=1iIb_ W6K7qE.

Stampnitzky, Lisa. 2013. Disciplining Terror: How Experts Invented 'Terrorism'. Cambridge ; New York: Cambridge University Press.

Stoltenberg, Thorvald. 2009. 'Nordic Cooperation on Foreign and Security Policy'. Ministry of Foreign Affairs Norway. www.mfa.is/media/Frettatilkynning/ Nordic_report.pdf. 
Sundelius, Bengt. 2001a. 'Totalförsvaret är överspelat - vi behöver ett samhällsförsvar'. Ministry of Defence Sweden. 2001.

Theiler, Tobias. 2003. 'Societal Security and Social Psychology'. Review of International Studies 29 (2): 249-268.

Total Defence Information Committee. 1980. 'The Swedish Total Defence'. Total Defence Information Committee.

Von Konow, Jan. 1961. Svenskt Totalförsvar. Folkförsvaret Förlags AB.

Wæver, Ole. 1993. 'Societal Security: The Concept'. In Identity, Migration, and the New Security Agenda in Europe. London: Pinter. 